\title{
Proteomic responses of fruits to environmental stresses
}

\section{Zhulong Chan*}

Key Laboratory of Plant Germplasm Enhancement and Specialty Agriculture, Wuhan Botanical Garden, Chinese Academy of Sciences, Wuhan, Hubei, China

\section{Edited by:}

Pingfang Yang, Chinese Academy of Sciences, China

Reviewed by:

Brett S. Phinney, University of

California Davis, USA

Subhra Chakraborty,

National Institute of Plant Genome

Research, India

\section{*Correspondence:}

Zhulong Chan, Key Laboratory

of Plant Germplasm Enhancement and Specialty Agriculture, Wuhan

Botanic Garden, Chinese Academy of Science, Wuchang District,

Wuhan, Hubei Province 430074,

China.

e-mail: zhulongch@wbgcas.cn
Fruits and vegetables are extremely susceptible to decay and easily lose commercial value after harvest. Different strategies have been developed to control postharvest decay and prevent quality deterioration during postharvest storage, including cold storage, controlled atmosphere (CA), and application of biotic and abiotic stimulus. In this review, mechanisms related to protein level responses of host side and pathogen side were characterized. Protein extraction protocols have been successfully developed for recalcitrant, low protein content fruit tissues. Comparative proteome profiling and functional analysis revealed that defense related proteins, energy metabolism, and antioxidant pathway played important roles in fruits in response to storage conditions and exogenous elicitor treatments. Secretome of pathogenic fungi has been well-investigated and the results indicated that hydrolytic enzymes were the key virulent factors for the pathogen infection. These protein level changes shed new light on interaction among fruits, pathogens, and environmental conditions. Potential postharvest strategies to reduce risk of fruit decay were further proposed based on currently available proteomic data.

Keywords: proteomics, postharvest, fruit, pathogen, induced resistance, secretome

\section{INTRODUCTION}

Fruits and vegetables are highly perishable horticultural products, especially during the ripening and postharvest stages, when considerable losses due to microbiological diseases, disorders, transpiration, and senescence can occur. Although quality deterioration of fresh postharvest fruits and vegetables is the result of a number of different factors, microbial activity is by far the single most important one (Sommer, 1982). In the developed countries, approximately $10-30 \%$ of harvested fruits and vegetables is lost due to postharvest spoilage, and in the developing countries the losses are over $30-50 \%$ annually due to lacking sanitation and refrigeration (Salunkhe et al., 1991; Legard et al., 2000).

The fruit-pathogen interaction depends on mutual recognition. Studies have been performed using classical genetics, cell biology, and biochemistry, as well as high-throughput-omic techniques (Chan and Tian, 2005, 2006; Chan et al., 2007; Qin et al., 2007). As a powerful tool, proteomics approach has been widely used to identify global changes in structure and abundance of plant proteins in response to developmental and environmental signals (Chan et al., 2007; Shi et al., 2008). There has been an increasing trend in application of proteomic methods to detect fruit and vegetable physiological changes over the last few years (Rocco et al., 2006; Chan et al., 2008; Pedreschi et al., 2008), offering to the research community the opportunity to unravel complex sets of proteins.

\section{DEVELOPMENT OF PROTEOMIC PROFILING PROTOCOLS FOR FRUITS AND VEGETABLES}

Today, proteomics techniques, including high-resolution two dimensional electrophoresis (2-DE), in-gel proteolytic digestion of protein spots and protein identification by MS through database searches, are increasingly used in studies of animals and microorganisms (Antelmann et al., 1997; Qin et al., 2007), and have been used successfully in plant biology to study changes in protein level expression during development (Chang et al., 2000; Chan et al., 2007). However, plant cells contain many components that may interfere with protein extraction, separation, and purification (Granier, 1988). Fruit tissues are difficult to process through proteomic approach partly due to technical problems such as the low protein content of fruit and the presence of an array of compounds, for example, pigments, starch, polyphenols, polysaccharides, tannins, and organic acids that can cause a high degree of protein denaturation and inactivation (Clements, 1970).

For good reproducibility of $2-\mathrm{DE}$, sample preparation is a critical step. The extraction of high-quality protein from recalcitrant, low protein content fruit tissue is a challenge. Several protein extraction protocols suitable for 2-DE have been developed. Major soluble proteins of grapevine ripe berries have been extracted from six different cultivars using TCA-acetone solution (TCA method) (Sarry et al., 2004), resulting in three hundreds detected spots on the 2-DE map after colloidal blue staining. Chan and co-authors have developed two additional protocols suitable for fruit protein extraction (Chan et al., 2007, 2008). In one protocol, fruit tissues were homogenized in homogenization buffer containing $20 \mathrm{mM}$ Tris- $\mathrm{HCl}$ (pH 7.5), $250 \mathrm{mM}$ sucrose, $10 \mathrm{mM}$ EGTA, $1 \mathrm{mM}$ phenylmethanesulfonyl fluoride (PMSF), $1 \mathrm{mM}$ dithiothreitol (DTT), and 1\% Triton X-100 before TCAacetone precipitation (Homo method) (Chan et al., 2007). In another protocol, extraction with an equal volume of Tris- $\mathrm{HCl}$ pH 7.8 buffered phenol was conducted after buffer homogenization but before methonal precipitation (Phe method) (Chan et al., 2008) (Figure 1). In comparison of these three protocols, Homo and Phe methods are much better than TCA method in 


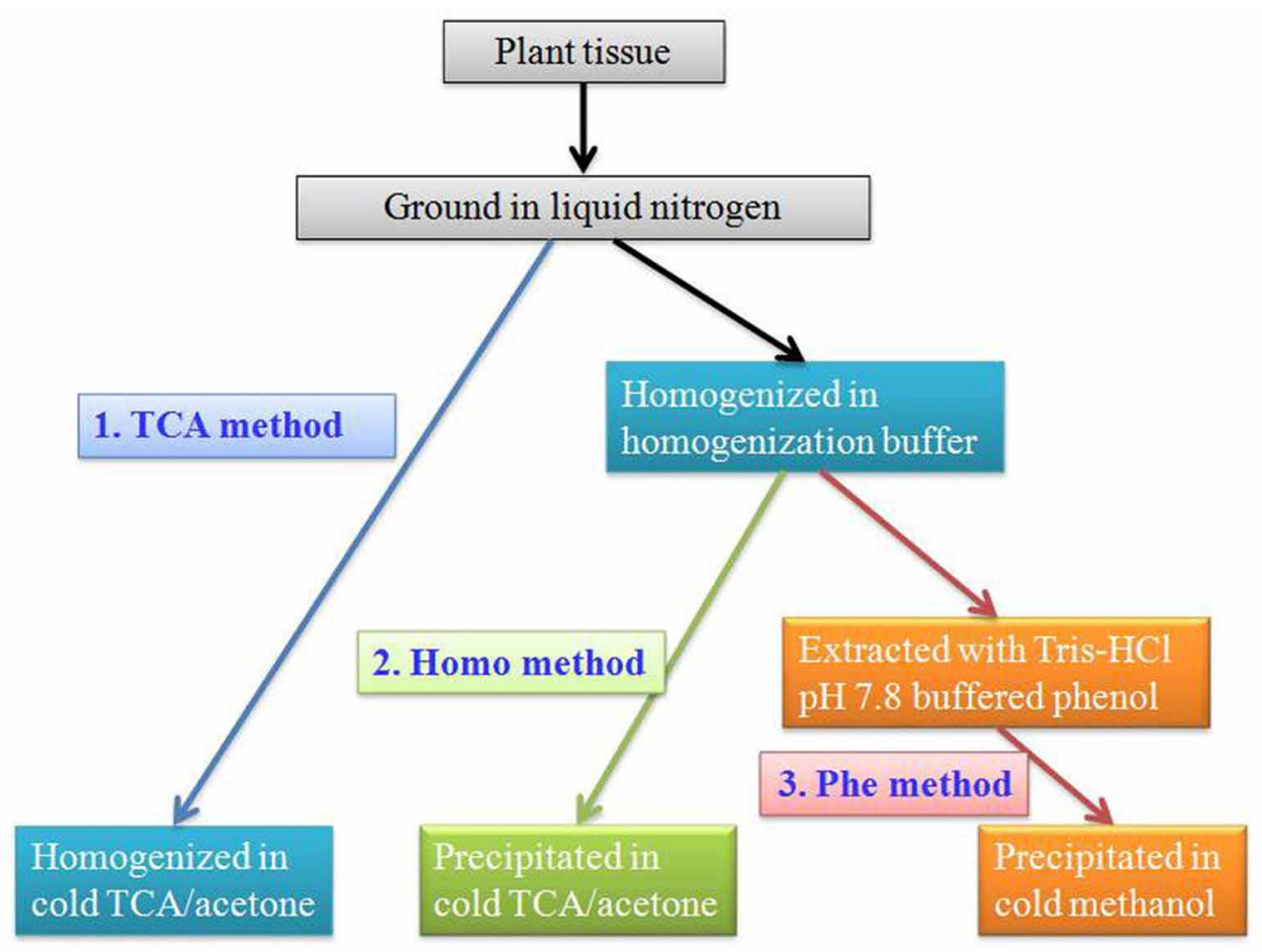

FIGURE 1 | Protein extraction protocols for fruits.

fruit protein extraction. Reproducible 2-DE results with wellresolved polypeptide spots throughout the gel were achieved by Homo and Phe protein extraction protocols for a variety of fruits, including sweet cherry (Prunus avivum), peach (Prunus persica), apple (Malus domestica), mango (Mangifera indica), and jujube (Ziziphus jujuba) fruits. This method can also be applied as a general method to other plant tissues that are rich in interfering compounds (Wang et al., 2009a).

\section{INTERACTION BETWEEN FRUITS AND FUNGI}

As mentioned above, many studies focused on the interactions between fruits and pathogens based on proteomics approach. However, the major problem is how to identify proteins from fruit-pathogen mixed samples. Therefore, few proteomic data are available for fruit (host) side and also for pathogen side in vivo. One possibility is that specific taxon should be used when mass spectrometry data were submitted to the website of Matrix Science for protein identification. After searching using both host taxon and pathogen taxon, we are able to tell where the proteins come from. Gray mold by Botrytis cinerea and green mold by Penicillium expansum, two major diseases caused enormous fruit decay and great economic losses, have been extensively studied by several research groups and part of the results were reviewed here.

\section{Botrytis cinerea}

$B$. cinerea is a pathogenic filamentous fungus which infects more than 200 plant species in a variety of organs including fruit, flowers, and leaves (Williamson et al., 1995; Fernández-Acero et al., 2011). The host range for B. cinerea infection includes economically important crops such as tomato, berries, chickpeas, french beans, and cut flowers as well as many fruits. The fungus causes the gray mold disease resulting in significant crop losses under different production conditions. Gray mold occurs over a wide geographical area, in the open field, in greenhouses and even in storages at $0-10^{\circ} \mathrm{C} . \mathrm{B}$. cinerea is the principal cause of pre- and post-harvest disease in grapes, berries, tomatoes, and many other crops (Elad, 1997; Williamson et al., 2007). Proteomic analysis of three types of tomato fruit infected by $B$. cinerea revealed that 186 tomato proteins were identified in common among red ripe and red ripe-equivalent ripening inhibited (rin) mutant tomato fruit infected by $B$. cinerea. However, the limited infections by $B$. cinerea of mature green wild type fruit resulted in 25 and 33\% fewer defense-related tomato proteins than in red and rin fruit, respectively (Shah et al., 2012).

The biology of $B$. cinerea has been studied extensively and the genome of the fungus has been sequenced (Elad et al., 2004; van Kan, 2006), including strain T4 (INRA/Genoscope: http://urgi.versailles.inra.fr/projects/Botrytis/) and strain B05.10 (Broad Institute, Massachusetts Institute of Technology, MIT, http://www.broad.mit.edu/annotation/genome/botrytis_cinerea/ Home.html). B. cinerea secretes a battery of enzymes utilized for the degradation and consumption of the host plant. In 2006, Fernández-Acero et al. reported the first approach to the proteome analysis of $B$. cinerea. Most of the identified spots may play a crucial role as pathogenicity or virulence factors, including some housekeeping enzymes, such as malate and glyceraldehyde dehydrogenases. In an attempt to identify putative fungal virulence factors, protein profile from two $B$. cinerea strains differing in virulence and toxin production were compared. Twenty seven 
protein spots were identified and a significant number of spots were identified as malate dehydrogenase and glyceraldehyde-3phosphate dehydrogenase, which could be ascribed to differences in virulence between strains (Fernández-Acero et al., 2007). Shotgun proteomics was successfully used to identify the secretome of $B$. cinerea grown in three culture conditions which differed by the carbon nutrients provided. A total of 126 proteins secreted by $B$. cinerea were identified, 13 of which were identified as pectinases, which play an important role in cell wall degradation and successful invasion (Shah et al., 2009). Furthermore, the effect of ambient $\mathrm{pH}$ on secretome of $B$. cinerea strain B05.10 was investigated with a comparative proteomic method. The results indicated that distinct differences in secretome of $B$. cinerea were found between $\mathrm{pH} 4$ and 6 treatments, and 47 differential spots, corresponding to 21 unique proteins, were identified. At $\mathrm{pH} 4$, more proteins related to proteolysis were induced, whereas most of up-accumulated proteins were cell wall degrading enzymes at pH 6 (Li et al., 2012).

\section{Penicillium expansum}

P. expansum, another widespread filamentous fungus, is a major causative agent of fruit decay with great economic losses. This strain is also of potential public health concern, because it produces toxic secondary metabolites, including patulin, citrinin, and chaetoglobosins (Andersen et al., 2004).

In a study to compare the cellular and extracellular proteomes of $P$. expansum, the results showed that several proteins related to stress response (glutathione $S$-transferase, catalase, and heat shock protein 60) and basic metabolism (glyceraldehyde3-phosphate dehydrogenase, dihydroxy-acid dehydratase, and arginase) were identified in the cellular proteome. Catalase and glutathione S-transferase, the two antioxidant enzymes, exhibited reduced levels of expression upon exposure to borate, which affects the virulence of the fungal pathogen. The extracellular proteome of $P$. expansum under stress condition with reduced virulence showed that the expression of three protein spots were repressed in the presence of borate and identified as the same hydrolytic enzyme, polygalacturonase (Qin et al., 2007).

Exogenous environmental conditions greatly affect infection of pathogens, including temperature, humility, $\mathrm{pH}$ value, and oxidative status. $\mathrm{H}_{2} \mathrm{O}_{2}$ is reported to have a direct antimicrobial effect and be involved in defense reactions activated in plant tissues upon pathogen attack (Mellersh et al., 2002). Plasma membrane damage was not the main reason for $\mathrm{H}_{2} \mathrm{O}_{2}$-induced death of the fungal pathogen. Proteomic analysis of the changes of total cellular proteins in $P$. expansum showed that a large proportion of the differentially expressed proteins appeared to be of mitochondrial origin, implying that mitochondria may be involved in this process. Further mitochondrial sub-proteomic analysis characterized a set of mitochondrial proteins, including respiratory chain complexes $\mathrm{I}$ and III, $\mathrm{F}_{1} \mathrm{~F}_{0}$ ATP synthase, and mitochondrial phosphate carrier protein which might be associated with fungal death caused by $\mathrm{H}_{2} \mathrm{O}_{2}$ (Qin et al., 2011). The $\mathrm{pH}$ value, as one of the most important environmental parameters, has critical influence on spore germination of P. expansum. Spore germination of $P$. expansum was obviously inhibited at $\mathrm{pH}$ 2.0 and 8.0. Comparative proteomics analysis revealed that 17 proteins involved in protein synthesis and folding were mainly down-regulated at $\mathrm{pH} 2.0$ and 8.0. These findings indicated that impairing synthesis and folding of proteins might be one of the main reasons account for ambient $\mathrm{pH}$ effect on spore germination of $P$. expansum (Li et al., 2010).

\section{INDUCED RESISTANCE (IR) OF FRUITS}

Traditionally, postharvest disease is often controlled by the application of synthetic fungicides (Eckert and Ogawa, 1988). However, chemical protection is discouraged due to problems related to fungicide toxicity, development of fungicide resistance by pathogens, and potential harmful effects on the environment and human health, alternatives to synthetic chemicals have been proposed (Eckert et al., 1994; Tian and Fan, 2000; Elad et al., 2004). The use of biologically based fungicides in conjunction with induced resistance (IR) was suggested as a feasible approach for reducing postharvest disease in harvested fruits and vegetables (Cook et al., 1999; Tian et al., 2001). IR is a plastic response, which diverts carbon and nitrogen resources from plant growth and reproduction to provide a long lasting and systemic resistance to a broad spectrum of pathogens and pests (Linda, 2001). Two types of IR are well-characterized. Systemic acquired resistance (SAR) is an active defense initiated by infection with certain necrotizing pathogens and confers resistance to secondary infection. SAR is effective against a broad-spectrum of pathogens including viruses, bacteria, fungi, and oomycetes (Ryals et al., 1996; Sticher et al., 1997). Inhibition of salicylic acid (SA) accumulation or biosynthesis impairs SAR (Gaffney et al., 1993). Induced systemic resistance (ISR) resembles SAR but is induced by root colonization of specific strains of non-pathogenic plant growthpromoting rhizobacteria in contrast to SAR that is induced by necrotizing pathogens. Unlike SAR, ISR is dependent on jasmonate and ethylene, independent on SA and not associated with $P R$ gene expression (van Loon, 1997). Molecularly, both SAR and ISR in Arabidopsis are intertwined through NPR1 gene (Figure 2).

In fruits, IR can be triggered by microbial biological agents (non-pathogens, avirulent forms of pathogens), physical agents (curing, $\gamma$-radiation, hot water brushing and UV-C light), certain chemical agents [DL-3-amino butyric acid (BABA), 1,2,3benzothiadiazole-7-carbothioic acid S-methyl ester (ASM), salicylic acid (SA), ethylene, harpin, 2,6-dichloroisonicotinic acid, jasmonic acid (JA), methyl jasmonate (MJ), Oxalic acid (OA), potassium and phosphates], and natural compounds (Chitosan and Margosan-O) (Tian and Chan, 2004). In many experiments, IR holds promise as a new technology for the control of postharvest diseases and has been proven to be effective in the laboratory and in a few field cases (Droby et al., 2001; El-Ghaouth et al., 2003; Chan et al., 2008). Mechanisms of IR have been well-characterized from cell structure, physiological, and biochemical changes. Proteomic studies shed a light on molecular changes of IR.

\section{MICROBIAL BIOLOGICAL AGENTS}

In recent years, considerable attention has been placed on postharvest application of antagonists for the inhibition of plant disease because of concerns about the application of 


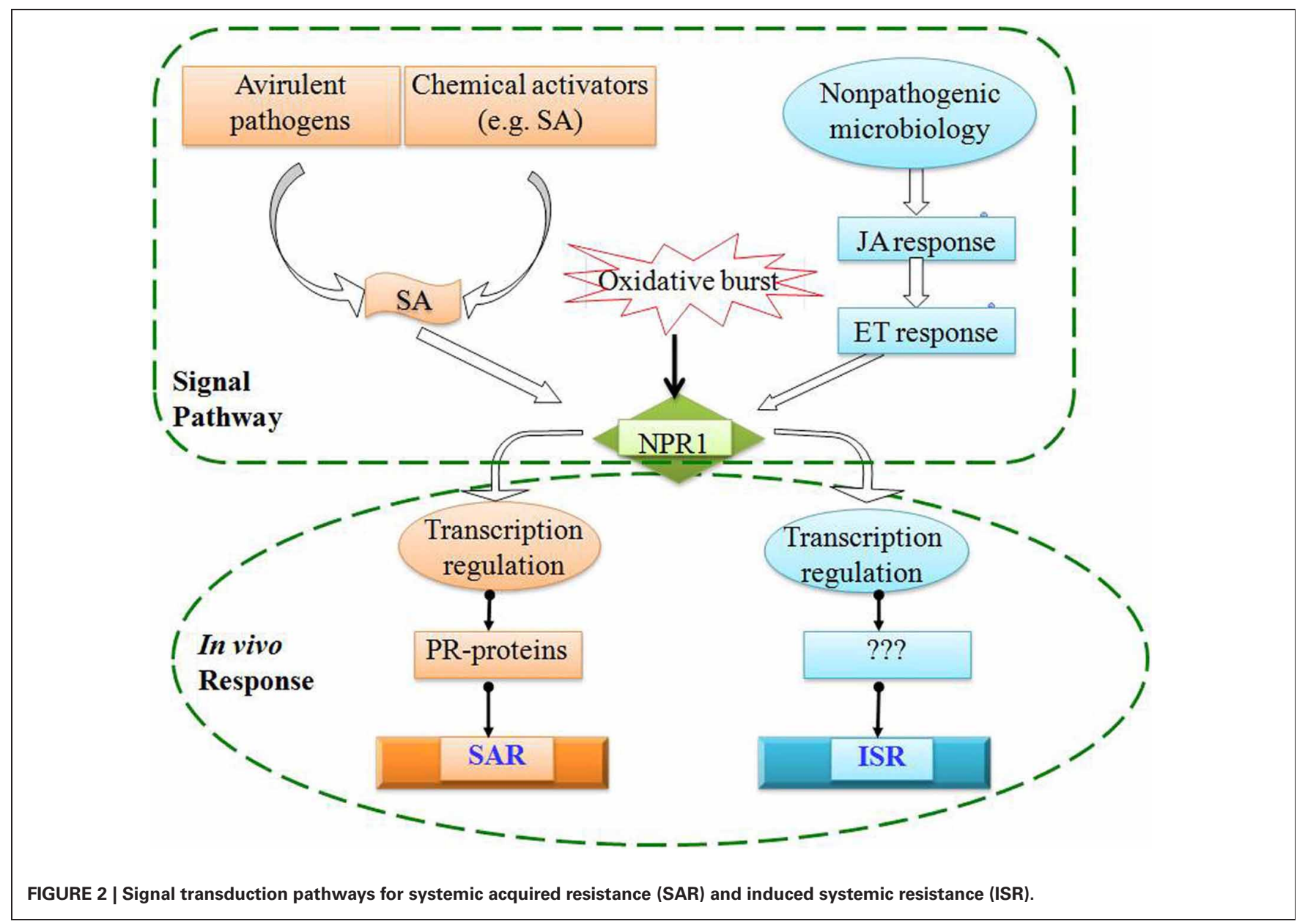

synthetic chemicals. Utilization of antagonistic yeasts as an alternative appears to be a promising technology (Droby et al., 2001; El-Ghaouth et al., 2003; Chan and Tian, 2006). Some antagonist-based products are commercially available and others are currently under varying degrees of development (Castoria et al., 2001).

Several mechanisms have been reported to play a significant role in the biocontrol activity of antagonistic yeasts, including direct interaction between antagonistic yeasts and pathogens (El-Ghaouth et al., 2003; Chan and Tian, 2005) and IR of fruit tissues by antagonistic yeasts (Droby et al., 2001; Chan and Tian, 2006; Chan et al., 2007). Significant changes in polyphenoloxidase (PPO), peroxidase (POD), catalase (CAT), superoxide dismutase (SOD), and phenylalanine ammonia-lyase (PAL) activities were found to be involved in the IR after antagonistic yeasts treatment (Fan and Tian, 2000; Qin et al., 2002; Chan and Tian, 2006). In harvested peach fruit, 19 proteins were identified using quadrupole time of-flight tandem mass spectrometer after treatment with antagonistic Pichia membranefaciens, including antioxidant related proteins, stress responsive proteins and proteins involved in energy pathways (Chan et al., 2007). These results suggested that antioxidant and PR proteins, as well as enzymes associated with sugar metabolism, were involved in resistance of peach fruit induced by P. membranefaciens.

\section{HEAT TREATMENT}

Pre-storage heat treatment is a promising postharvest method for reducing disease incidence and severity (Terry and Joyce, 2004; Schirra et al., 2011). Pre- and post-harvest heat treatments increased the resistance of cherry tomato (Zhao et al., 2009), bamboo shoots (Luo et al., 2012), fresh cut broccoli (Moreira Mdel et al., 2011), strawberry (Marquenie et al., 2002; Villa-Rojas et al., 2011), lemon (Nafussi et al., 2001) against postharvest decay, and reduced the development of green mold on citrus fruit (Schirra et al., 2008a), blue mold on pear (Schirra et al., 2008b), and peach (Zhang et al., 2007).

Based on the 2D-DIGE analysis, 52 proteins were differentially expressed between peach fruits exposed to heat treatment or after transfer to $20^{\circ} \mathrm{C}$, vs. fruits kept at $20^{\circ} \mathrm{C}$. Among identified spots, a large number (93\%) have been proposed to play a role in plant metabolism such as the defense and stress response, cytoskeleton organization, primary metabolism, transcription and translation regulation, and protein storage and catabolism. The category of proteins participating in biotic or abiotic stress responses was the one with the most proteins differentially expressed. Additionally, one third of the identified proteins corresponded to the large family of HSPs and exhibited molecular masses $<20 \mathrm{kDa}$, indicating that the induction of small HSPs in heated peach may participate in the acquisition of tolerance against some chilling 
injury symptoms (Lara et al., 2009). Another study demonstrated that among the thirty protein spots in peach fruit induced by heat treatment, $43 \%$ were related to stress response, $17 \%$ to cell structure, $13 \%$ to protein fate, $7 \%$ to glycolytic pathway, $3 \%$ to ripening and senescence, and $17 \%$ to unclassified (Zhang et al., 2011). The commonly induced proteins from both groups included ascorbate peroxidase, heat shock proteins, and allergen proteins, indicating these proteins are heat inducible proteins in peach fruit.

In citrus fruit, heat treatment induces defense mechanisms and triggers physiological responses to withstand stressful conditions during storage. Functional classification of twenty eight differentially expressed proteins showed that the main affected categories were "Cell rescue, defense, and virulence" and "Metabolism." Activity of antioxidant enzymes was extensively changed upon heat treatment, including SOD, POD and alcohol dehydrogenase (Perotti et al., 2011).

\section{CHEMICAL AGENTS}

Certain chemicals, including SA and OA, emerged as potentially effective agents to IR in fruits. SA has emerged as a key signaling component involved in the activation of certain plant defense responses (Durner et al., 1997). Exogenous application of SA protects plants against certain pathogens and activates SAR in a wide variety of plant species, including harvested fruit (van Loon, 1997; Yao and Tian, 2005). SA treatment IR to MYMIV infection in Vigna mungo. Twenty-nine proteins identified by MALDI-TOF/TOF, predicted to be involved in stress responses, metabolism, photosynthesis, transport, and signal transduction, showed increased abundance upon SA treatment. SA treatment stimulated SOD and POD activity and inhibited CAT activity thus preventing ROS mediated damage (Kundu et al., 2011). In harvested peach fruit, thirteen SA induced proteins were identified and the functions of these proteins were mainly involved in antioxidant and energy pathway (Chan et al., 2007). Pre-harvest application of SA solution enhanced the resistance of sweet cherry fruits against $P$. expansum, resulting in lower disease incidences and smaller lesion diameters, especially at earlier maturity stage. Totally 13 and 28 proteins were identified after SA treatment at earlier (A) and later (B) maturity stage, respectively. Antioxidant proteins and pathogenesis related-proteins were identified at both $A$ and B stages, while heat shock proteins and dehydrogenases involved in glycolysis and tricarboxylic acid cycle were only detected at B stage (Chan et al., 2008). All these results indicated that antioxidant related proteins as well as proteins involved energy metabolism play key roles in SA induced resistance in fruits.

$\mathrm{OA}$ is an organic acid distributing widely in various organisms, especially in plants (Franceschi and Nakata, 2005). Recent studies revealed that OA might play important roles in systemic resistance, stress response, programmed cell death and redox homeostasis in plant (Guo et al., 2005; Kim et al., 2008). Recent studies showed that application of OA extend postharvest and shelf life in litchi (Zheng and Tian, 2006), mango (Zheng et al., 2007a), peach (Zheng et al., 2007b), jujube (Wang et al., 2009b), and plum (Wu et al., 2011) fruits. The application of oxalic acid reduced ethylene production and delayed softening of plum fruit. During storage or shelf-life, flesh reddening and anthocyanin synthesis were significantly inhibited in oxalic acid-treated plum fruit, accompanied with decreased PAL activity (Wu et al., 2011). In jujube fruit, application of OA at the concentration of $5 \mathrm{mM}$ could delay fruit senescence by reducing ethylene production, repressing fruit reddening and reducing alcohol content, which consequently increased fruit resistance against blue mold caused by $P$. expansum. A total of 25 differentially expressed proteins were identified after OA treatment. The activity of alcohol dehydrogenase 1 and 1-aminocyclopropane1 -carboxylic acid synthase was repressed, while the abundances of three photosynthesis-related proteins, a cystathionine $\beta$ synthase domain-containing protein and three proteins related to the defense/stress response were up-regulated by OA. These results indicated that $\mathrm{OA}$ treatment might affect ethanol and ethylene metabolism, resulting in delaying senescence, and increase resistance of jujube fruits against fungal pathogens (Wang et al., 2009b).

\section{PROTEOME-LEVEL RESPONSES OF FRUITS TO STORAGE ENVIRONMENTS COLD STORAGE}

Cold storage is one of the most frequently employed methods to delay fruit senescence and maintain fruit quality during postharvest storage. Generally speaking, fruits taste good with a total soluble sugar/total organic acid ratio over 8 and low temperature (LT) is applied in inhibiting the ratio increase (Yun et al., 2012). Under LT condition, a total of 108 differentially accumulated protein spots in citrus were analyzed by MALDI-TOF MS/MS, and 63 spots were successfully identified on the basis of tryptic peptide sequences. The results showed that metabolism pathway and stress response related categories were considerably enriched, including sugars and polysaccharide metabolism, secondary metabolism, protein destination and storage, and response to stimulus (Yun et al., 2012). Moreover, fruit maintains low accumulation of ROS, low level of membrane lipid peroxidation, greater flesh firmness and higher concentrations of organic acids and, vitamin levels (Kan et al., 2011; Yun et al., 2012). These results indicated that these processes play a leading role in the maintenance of fruit quality and delaying of senescence at LT.

Interestingly, peach fruit is less prone to chilling injury when stored at $0^{\circ} \mathrm{C}$ than at $5^{\circ} \mathrm{C}$ (Zhang et al., 2010). Further study using proteomics approach indicated that several membrane stability related proteins were enhanced, while proteins related to phenolic compounds metabolization were repressed in peach fruit at $0^{\circ} \mathrm{C}$ relative to $5^{\circ} \mathrm{C}$. Other proteins involved in sugar metabolism and energy pathways were decreased at $0^{\circ} \mathrm{C}$, resulting in the lower assumption of sugars which has several beneficial effects in protecting plants against stresses (Zhang et al., 2010). When stored at LTs, 55 proteins from bell pepper (Capsicum annuum) fruits were identified as having differential abundances. Redox and carbohydrate metabolism were the two major functional classes found in a proteomic study (Sánchez-Bel et al., 2012).

Dehydrin is known as a group 2 late embryogenesis abundant (LEA) proteins, one of several ubiquitous water-stress-responsive proteins in plants (Close, 1997). Several individual groups identified dehydrin protein in peach and citrus fruit stored 
at LT through traditional 2D-PAGE and difference gel electrophoresis (DIGE) (Nilo et al., 2010; Yun et al., 2010, 2012; Zhang et al., 2010). Other commonly identified proteins by these groups included heat shock protein and dehydrogenase which were well-known to play a key role in plant stress responses (Giannino et al., 2004; Posner et al., 2012). In nectarine fruits stored at LT, four differentially expressed proteins were characterized as allergens which can provide some form of protection to fruits during periods of stress (Pedreschi et al., 2007; Giraldo et al., 2012).

\section{CONTROLLED ATMOSPHERE (CA)}

Fruit are often stored under controlled atmosphere (CA) conditions with low- $\mathrm{O}_{2}$ and high- $\mathrm{CO}_{2}$ at LT to reduce respiration, ethylene production rates and action, delay ripening and senescence, as well as to reduce the growth of pathogens (Kader, 2002). When loquat (Eriobotrya japonica Lindl.) fruit were stored under different storage conditions, CA with $10 \% \mathrm{O}_{2}+1 \% \mathrm{CO}_{2}$ was more effective in reducing fruit decay. Loquat fruit could be stored in this $\mathrm{CA}$ condition at $1^{\circ} \mathrm{C}$ for more than $50 \mathrm{~d}$ with normal flavor and low decay index of about 7\%. CA conditions were more effective in reducing the activities of PPO and oxidative stress compared to other treatments (Ding et al., 2006). The same results were achieved that CA conditions were more effective in reducing total phenol content, delaying anthocyanidin decomposition, preventing pericarp browning, and decreasing Litchi (Litchi chinensis Sonn. cv Heiye) fruit decay in comparison with other treatments (Tian et al., 2005a). Proteomic analysis revealed that several proteins were significantly changed in pear during CA conditions. Triosephosphate isomerase, a key enzyme of the energy metabolism was up-regulated under browning-inducing conditions. ACC oxidase involved in ethylene biosynthesis and the major allergen Pyrc 1 were clearly down-regulated under low oxygen or high carbon dioxide concentrations. Stress responsive proteins, like the chaperone molecule HSP70, were also downregulated as the oxygen concentration diminished (Pedreschi et al., 2008).

\section{PROTEOME-LEVEL CHANGES DURING FRUIT DEVELOPMENT AND RIPENING}

Fruit ripening is a developmental complex process which occurs in higher plants and involves a number of stages displayed from immature to mature fruits that depend on the plant species and the environmental conditions (Palma et al., 2011). The pathways involved in the processes of fruit development and ripening are exclusive for plants and vary between species. Based on ethylene production, two types of fruits were characterized, i.e., either climateric or non-climateric. Climacteric fruits, such as tomato, papaya, peach, apple, pear, banana, plum, and melon, are characterized by a dramatic increase in ethylene production, which is responsible for the typical respiratory burst during ripening, and the activation of many biochemical steps (Barry and Giovannoni, 2007; Palma et al., 2011). On the other hand, ripening of nonclimateric fruits such as pepper, citrus, orange, cucumber, grape, cherry, and strawberry is ethylene-independent (Palma et al., 2011).

\section{CLIMATERIC FRUITS}

In young tomato fruit, intensity of proteins involved in amino acid metabolism and protein synthesis increased during the early development (cell division) stage. During the later development (cell expansion) stage, proteins functioning in photosynthesis and cell wall formation transiently increased. In contrast, many proteins related to $\mathrm{C}$ compounds and carbohydrate metabolism or oxidative processes were up-regulated during fruit development (Faurobert et al., 2007). In papaya, six main categories, including cell wall, ethylene biosynthesis, climacteric respiratory burst, stress response, synthesis of carotenoid precursors, and chromoplast differentiation were found to be related to fruit ripening using 2DE-DIGE (Nogueira et al., 2012). Based on traditional 2D-PAGE, several cell wall degrading enzymes related to fruit ripening were identified in papaya fruit (Huerta-Ocampo et al., 2012). In peach fruit, the functions of 30 identified proteins were involved in primary metabolism (e.g., C-compounds, carbohydrates, organic acids, and amino acids) and in ethylene biosynthesis as well as proteins involved in secondary metabolism and responses to stress (Prinsi et al., 2011). A further study to characterized the protein accumulation patterns in firm and soft fruit of three peach and two nectarine melting flesh varieties revealed that 164 of the 621 protein spots analyzed displayed a differential accumulation associated with the softening process. Among them, only 14 proteins changed their accumulation in all the varieties assessed, including proteins mostly involved in carbohydrates and cell wall metabolism as well as fruit senescence (Nilo et al., 2012). Moreover, in kiwifruit, which displays climacteric behavior at temperatures above $20^{\circ} \mathrm{C}$ (Antunes, 2007), proteomic analysis using $1 \mathrm{D}$-SDS-PAGE and mass spectrometry identified 102 kiwifruit proteins during ripening, which are mainly involved in energy, protein metabolism, defense, and cell structure. Ripening induced protein carbonylation in kiwifruit but this effect was depressed by ozone (Minas et al., 2012).

\section{NON-CLIMATERIC FRUITS}

The proteins identified as differentially accumulated during ripening of strawberry fruit are involved in a wide range of biological processes such as energy and carbon metabolisms, secondary metabolism/biosynthesis of cellular components, cellular organization, communication and signal transduction, protein metabolism, stress response, and transcription. Most of identified proteins showed a regular increase in spot volume from the immature to the mature stage indicating they are progressively involved during ripening (Bianco et al., 2009). Grape is another non-climateric important crop species for human nutrition and agricultural economy. The proteomic analysis using grape skin tissue revealed that the most relevant changes in protein expression occurred in the first weeks of ripening. Many of these variations were related to proteins involved in responses to stress, glycolysis and gluconeogenesis, C-compounds and carbohydrate metabolism, and amino acid metabolism (Negri et al., 2008). Another study revealed that proteins involved in photosynthesis, carbohydrate metabolisms, and stress response are identified as being enriched at the beginning of color-change. The end of color-change is characterized by the enrichment of proteins involved in anthocyanin synthesis and, at harvest, the 
dominant proteins are involved in defense mechanisms. In particular, the abundance of different chitinase and beta-1,3-glucanase isoforms increased as the berry ripens, indicating these enzymes were involved in softening during fruit ripening (Deytieux et al., 2007).

\section{TOOLS FOR FRUIT PROTEOME PROFILING}

Traditional large scale proteomic analysis usually relies on $2 \mathrm{D}$ gel electrophoresis (2DE), i.e., separation by $2 \mathrm{DE}$, protein spot digestion with a protease, and MS identification. However, gel electrophoresis is poorly compatible with high-throughput MS analysis. More recently, gel free technology has been welldeveloped, which includes steps of protease digestion of the protein mix, LC separation of peptides, and MS identification. Though the 2DE is still the most commonly used method, gel free based protein separation approaches, like MudPIT (multidimensional protein identification technology), DIGE (2D-difference gel electrophoresis), iTRAQ (Isobaric tag for relative and absolute quantitation), SILAC (stable isotope labeling by amino acids in cell culture), ICAT (isotope coded affinity tags), and LOPIT (localization of organelle proteins by isotope tagging), are potentially powerful tools for fruit proteomes analyses.

2D-DIGE is a powerful technique for quantitatively comparing different samples labeled with different dyes. Using this technology, 37 proteins showing different abundance during papaya fruit ripening were characterized and submitted to MS analysis (Nogueira et al., 2012). In addition, approximately 2500 protein spots were successfully resolved from ripening strawberry fruit 2D-DIGE gel (Bianco et al., 2009). In iTRAQ, peptides derived from each sample are derivatized with amine-specific isobaric tags which are indistinguishable by MS but exhibit MS/MS signature ions. A total of 1664 proteins were identified from orange by the iTRAQ technique (Ai et al., 2012). Researchers also successfully identified genetically engineered tomato using iTRAQ and MudPIT methods (Robertson et al., 2012). These non-gel based approaches are complementary to gel-based ones and together the different techniques allow for improved proteomic coverage (Quirino et al., 2010).

\section{CONCLUDING REMARKS AND FUTURE PROSPECT}

Proteomics approach is not only a powerful tool to dissect fundamental level changes, but for selection of appropriate markers (proteins) so as to be able to detect metabolic disorders in harvested fruits at an early stage and identify virulent factors involved in pathogen infection. Based on proteomic studies, proteins involved in different metabolic pathways in fruit were activated after postharvest treatments. Therefore, to reduce postharvest decay and thus minimize ecological losses, biologists should firstly pay more attentions to combination treatments. Several pioneering works have been

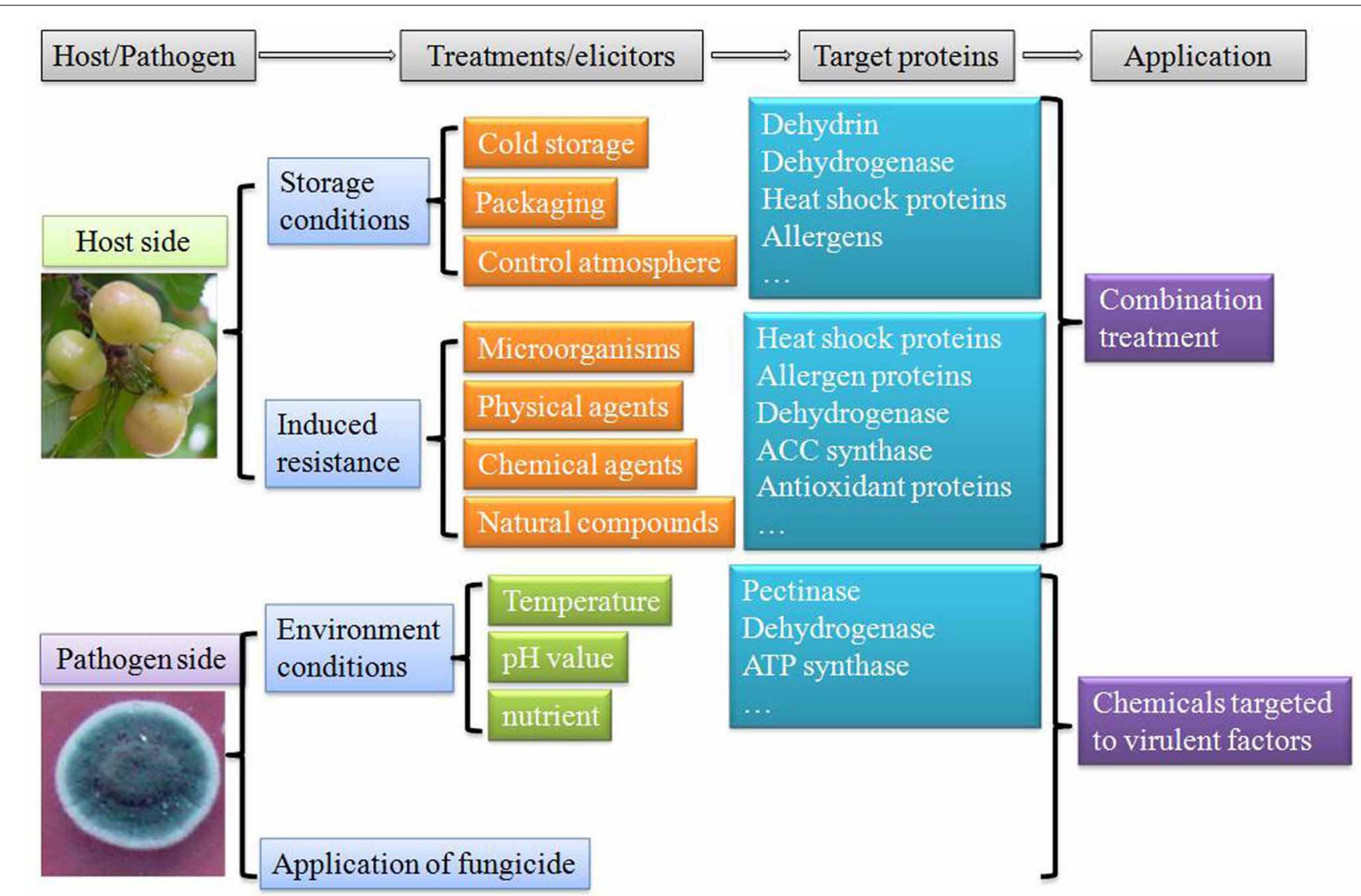

FIGURE 3 | Approaches to control postharvest decay and mechanisms involved based on proteomic study. 
carried out to control postharvest diseases by combining different approaches (Tian et al., 2005b; Palou et al., 2007; Sivakumar et al., 2008; Wang et al., 2011). Combination treatments showed improved control efficiency to reduce fruit disorder and decay, and maintain fruit quality during postharvest storage and transportation. Moreover, proteomic approach from the pathogen side also revealed that virulent factors play key roles during pathogen infection. Specific medicines targeted to these proteins could be designed to inhibit the development and growth of pathogens (Figure 3). Through these two strategies the biologists were able to more effectively protect the fruit from the infection of postharvest pathogens. Further researches combining proteomic, transcriptomic, and metabolic approaches are also needed to characterize mechanisms involved in interactions among fruits, pathogens and environmental conditions.

\section{ACKNOWLEDGMENTS}

This work was supported by "the Hundred Talents Program" and the Knowledge Innovation Program of Chinese Academy of Sciences (54Y154761O01076).

\section{REFERENCES}

Ai, X. Y., Lin, G., Sun, L. M., Hu, C. G., Guo, W. W., Deng, X. X., et al. (2012). A global view of gene activity at the flowering transition phase in precocious trifoliate orange and its wild-type [Poncirus trifoliata (L.) Raf.] by transcriptome and proteome analysis. Gene 510, 47-58.

Andersen, B., Smedsgaard, J., and Frisvad, J. C. (2004). Penicillium expansum: consistent production of patulin, chaetoglobosins, and other secondary metabolites in culture and their natural occurrence in fruit products. J. Agric. Food Chem. 52, 2421-2428.

Antelmann, H., Bernhardt, J., Schmid, R., Mach, H., Völker, U., and Hecker, P. M. (1997). First steps from a two-dimensional protein index towards a responseregulation map for Bacillus subtilis. Electrophoresis 18, 1451-1463.

Antunes, M. D. C. (2007). The role of ethylene in kiwifruit ripening and senescence. Stewart Postharvest Rev. 3, 1-8.

Barry, C. S., and Giovannoni, J. J. (2007). Ethylene and fruit ripening. J. Plant Growth Regul. 26, 143-159.

Bianco, L., Lopez, L., Scalone, A. G., Di Carli, M., Desiderio, A., Benvenuto, E., et al. (2009). Strawberry proteome characterization and its regulation during fruit ripening and in different genotypes. J. Proteomics 72, 586-607.

Castoria, R., de Curtis, F., Lima, G., Caputo, L., Pacifico, S., and de Cicco, V. (2001). Aureobasidium pullulans (LS-30) an antagonist of postharvest pathogens of fruit: study on its modes of action. Postharvest Biol. Technol. 2, 7-17.

Chan, Z. L., Qin, G. Z., Xu, X. B., Li, B. Q., and Tian, S. P. (2007). Proteome approach to characterize proteins induced by antagonist yeast and salicylic acid in peach fruit. J. Proteome Res. 6, 1677-1688.

Chan, Z. L., and Tian, S. P. (2005). Interaction of antagonistic yeasts against postharvest pathogens in apple fruit and possible mode of action. Postharvest Biol. Technol. 36, 215-223.

Chan, Z. L., and Tian, S. P. (2006). Induction of $\mathrm{H}_{2} \mathrm{O}_{2}$-metabolizing enzymes and total protein synthesis in sweet cherry fruit by salicylic acid and antagonistic Pichia membranefaciens. Postharvest Biol. Technol. 39, 314-320.

Chan, Z. L., Wang, Q., Xu, X. B., Meng, X. H., Xu, Y., Qin, G. Z., et al. (2008). Functions of defenserelated proteins and dehydrogenases in resistance response induced by salicylic acid in sweet cherry fruits at different maturity stages. Proteomics 8, 4791-4807.

Chang, W., Huang, L., Shen, M., Webster, C., Burlingame, A. L., and Roberts, J. K. (2000). Patterns of protein synthesis and tolerance of anoxia in root tips of maize seedlings acclimated to a low-oxygen environment, and identification of proteins by mass spectrometry. Plant Physiol. 122, 295-318.

Clements, R. L. (1970). "Protein patterns in fruits," in The Biochemistry of Fruit and Their Products. ed A. C. Hulme (London; New York, NY: Academic Press), 159-177.

Close, T. J. (1997). Dehydrins: a commonalty in the response of plants to dehydration and low temperature. Physiol. Plant. 100, 291-296.

Cook, D. W. M., Long, P. G., and Ganesh, S. (1999). The combined effect of delayed application of yeast biocontrol agents and fruit curing for the inhibition of the postharvest pathogen Botrytis cinerea in kiwifruit. Postharvest Biol. Technol. 16, 233-243.

Deytieux, C., Geny, L., Lapaillerie, D., Claverol, S., Bonneu, M., and Doneche, B. (2007). Proteome analysis of grape skins during ripening. J. Exp. Bot. 58, 185-1162.

Ding, Z. S., Tian, S. P., Wang, Y. S., Chan, Z. L., Han, J., and Xu, Y. (2006). Physiological response of loquat fruit to different storage conditions and its storability. Postharvest Biol. Technol. 41, 143-150.

Droby, S., Vinokur, V., Weiss, B., Cohen, L., Daus, A., Goldschmidt, E. E., et al. (2001). Induction of resistance to Penicillium digitatum by the yeast biocontrol agent Candida oleophila. Phytopathology 92, 393-399.

Durner, J., Shah, J., and Klessig, D. F. (1997). Salicylic acid and disease resistance in plants. Trends Plant Sci. 2, 266-274.

Eckert, J. W., and Ogawa, J. M. (1988). The chemical control of vegetables and root tuber crops. Annu. Rev. Phytopathol. 26, 433-446.

Eckert, J. W., Sievert, J. R., and Ratnayake, M. (1994). Reduction of imazalil effectiveness against citrus green mold in California packinghouse by resistant biotypes of Penicillium digitatum. Plant Dis. 78, 791-794.

Elad, Y. (1997). Responses of plants to infection by Botrytis cinerea and novel means involved in reducing their susceptibility to infection. Biol. Rev. Camb. Philos. Soc. 72, 381-422.

Elad, Y., Williamson, B., Tudzynski, P., and Delen, N. (2004). "Botrytis spp. and diseases they cause in agricultural systems- an introduction." in Botrytis: Biology, Pathology and Control, eds Y. Elad, B. Williamson, P. Tudzynski, and N. Delen (Dordrecht: Kluwer Academic Publishers), 1-8.

El-Ghaouth, A., Wilson, C. L., and Wisniewski, M. (2003). Control of postharvest decay of apple fruit with Candida saitoana and induction of defense responses. Phytopathology 93, 344-348.

Fan, Q., and Tian, S. P. (2000). Postharvest biological control of Rhizopus rot on nectarine fruit by Pichia membranefaciens Hansen. Plant Dis. 84, 1212-1216.

Faurobert, M., Mihr, C., Bertin, N., Pawlowski, T., Negroni, L., Sommerer, N., et al. (2007). Major proteome variations associated with cherry tomato pericarp development and ripening. Plant Physiol. 143, 1327-1346.

Fernández-Acero, F. J., Carbú, M., El-Akhal, M. R., Garrido, C., González-Rodríguez, V. E. and Cantoral, J. M. (2011). Development of proteomicsbased fungicides: new strategies for environmentally friendly control of fungal plant diseases. Int. J. Mol. Sci. 12, 795-816.

Fernández-Acero, F. J., Jorge, I., Calvo, E., Vallejo, I., Carbú, M., Camafeita, E., et al. (2007). Proteomic analysis of phytopathogenic fungus Botrytis cinerea as a potential tool for identifying pathogenicity factors, therapeutic targets and for basic research. Arch. Microbiol. 187, 207-215.

Fernández-Acero, F. J., Jorge, I., Calvo, E., Vallejo, I., Carbú, M., Camafeita, L. E., et al. (2006). Two-dimensional electrophoresis protein profile of the phytopathogenic fungus Botrytis cinerea. Proteomics 6, S88-S96.

Franceschi, V. R., and Nakata, P. A. (2005). Calcium oxalate in plants: formation and function. Annu. Rev. Plant Biol. 56, 41-71.

Gaffney, T., Friedrich, L., Vernooij, B., Negrotto, D., Nye, G., Uknes, S., et al. (1993). Requirement of salicylic acid for the induction of systemic acquired resistance. Science 261, 754-756.

Giannino, D., Condello, E., Bruno, L., Testone, G., Tartarini, A., Cozza, R., et al. (2004). The gene geranylgeranyl reductase of peach (Prunus persica [L.] Batsch) is regulated during leaf development and responds differentially to distinct stress factors. J. Exp. Bot. 55, 2063-2073.

Giraldo, E., Díaz, A., Corral, J. M., and García, A. (2012). Applicability of 2-DE to assess differences in the protein profile between cold storage and not cold storage in nectarine fruits. J. Proteomics 75 5774-5782. 
Granier, F. (1988). Extraction of plant proteins for two-dimensional electrophoresis. Electrophoresis 9, 712-718.

Guo, Z., Tan, H., Zhu, Z., Lu, S., and Zhou, B. (2005). Effect of intermediates on ascorbic acid and oxalate biosynthesis of rice and in relation to its stress resistance. Plant Cell Physiol. 43, 955-962.

Huerta-Ocampo, J. Á., Osuna-Castro, J. A., Lino-López, G. J., BarreraPacheco, A., Mendoza-Hernández, G., De León-Rodríguez, A., et al. (2012). Proteomic analysis of differentially accumulated proteins during ripening and in response to 1 MCP in papaya fruit. J. Proteomics $75,2160-2169$.

Kader, A. A. (2002). Postharvest Technology of Horticultural Crops. 3rd Edn. Publication 3311. Davis, CA: University of California, Agriculture and Natural Resources, 535.

Kan, J., Wang, H. M., and Jin, C. H. (2011). Changes of reactive oxygen species and related enzymes in mitochondrial respiration during storage of harvested peach fruits. Agric. Sci. China 10, 149-158.

Kim, K. S., Min, J. Y., and Dickman, M. B. (2008). Oxalic acid is an elicitor of plant programmed cell death during Sclerotinia sclerotiorum disease development. Mol. Plant Microbe Interact. 21, 605-612.

Kundu, S., Chakraborty, D., and Pal, A. (2011). Proteomic analysis of salicylic acid induced resistance to Mungbean Yellow Mosaic India Virus in Vigna mungo. J. Proteomics 74, 337-349.

Lara, M. V., Borsani, J., Budde, C. O., Lauxmann, M. A., Lombardo, V. A., Murray, R., et al. (2009). Biochemical and proteomic analysis of 'Dixiland' peach fruit (Prunus persica) upon heat treatment. J. Exp. Bot. 60, 4315-4333.

Legard, D. E., Xiao, C. L., Merteley, J. C., and Chandler, C. K. (2000). Effects of plant spacing and cultivar on the incidence of Botrytis fruit rot in annual strawberry. Plant Dis. 84, 531-538.

Li, B. Q., Lai, T. F., Qin, G. Z., and Tian, S. P. (2010). Ambient pH stress inhibits spore germination of Penicillium expansum by impairing protein synthesis and folding: a proteomic-based study. J. Proteome Res. 9, 298-307.

Li, B. Q., Wang, W. H., Zong, Y. Y., Qin, G. Z., and Tian, S. P. (2012). Exploring pathogenic mechanisms of Botrytis cinerea secretome under different ambient $\mathrm{pH}$ based on comparative proteomic analysis. J. Proteome Res. 11, 4249-4260.

Linda, L. W. (2001). Induced resistance: from the basic to the applied. Trends Plant Sci. 6, 445-447.

Luo, Z., Feng, S., Pang, J., Mao, L., Shou, H., and Xie, J. (2012). Effect of heat treatment on lignification of postharvest bamboo shoots (Phyllostachys praecox f. prevernalis.). Food Chem. 135, 2182-2187.

Marquenie, D., Michiels, C. W., Geeraerd, A. H., Schenk, A., Soontjen, C., Van Impe, J. F., et al. (2002). Using survival analysis to investigate the effect of UV-C and heat treatment on storage rot of strawberry and sweet cherry. Int. J. Food Microbiol. 73, 187-196.

Mellersh, D. G., Foulds, I. V., Higgins, V. J., and Heath, M. C. (2002). $\mathrm{H}_{2} \mathrm{O}_{2}$ plays different roles in determining penetration failure in three diverse plant-fungal interactions. Plant J. 29, 257-268.

Minas, I. S., Tanou, G., Belghazi, M., Job, D., Manganaris, G. A., Molassiotis, A., et al. (2012). Physiological and proteomic approaches to address the active role of ozone in kiwifruit postharvest ripening. J. Exp. Bot. 63, 2449-2464.

Moreira Mdel, R., Ponce, A., Ansorena, R., and Roura, S. I. (2011). Effectiveness of edible coatings combined with mild heat shocks on microbial spoilage and sensory quality of fresh cut broccoli (Brassica oleracea L.). J. Food Sci. 76, M367-M374.

Nafussi, B., Ben-Yehoshua, S., Rodov, V., Peretz, J., Ozer, B. K., and D'hallewin, G. (2001). Mode of action of hot-water dip in reducing decay of lemon fruit. J. Agric. Food Chem. 49, 107-113.

Negri, A. S., Prinsi, B., Rossoni, M. Failla, O., Scienza, A., Corucci, M., et al. (2008). Proteome changes in the skin of the grape cultivar Barbera among different stages of ripening. BMC Genomics 9:378. doi: 10.1186/1471-2164-9-378

Nilo, P. R., Campos-Vargas, R., and Orellana, A. (2012). Assessment of Prunus persica fruit softening using a proteomics approach. J. Proteomics 75, 1618-1638.

Nilo, R., Saffie, C., Lilley, K., Baeza-Yates, R., Cambiazo, V., Campos-Vargas, R., et al. (2010). Proteomic analysis of peach fruit mesocarp softening and chilling injury using difference gel electrophoresis (DIGE). BMC Genomics 11:43. doi: 10.1186/1471-2164-11-43
Nogueira, S. B., Labate, C. A., Gozzo, F. C., Pilau, E. J., Lajolo, F. M., and Oliveira do Nascimento, J. R. (2012). Proteomic analysis of papaya fruit ripening using 2DEDIGE. J. Proteomics 75, 1428-1439.

Palma, J. M., Corpas, F. J., and del Río, L. A. (2011). Proteomics as an approach to the understanding of the molecular physiology of fruit development and ripening. J. Proteomics 74, 1230-1243.

Palou, L., Crisosto, C. H., and Garner D. (2007). Combination of postharvest antifungal chemical treatments and controlled atmosphere storage to control gray mold and improve storability of "Wonderful" pomegranates. Postharvest Biol. Technol. 43, 133-142.

Pedreschi, R., Hertog, M., Robben, J., Noben, J.-P., and Nicolaï, B. (2008). Physiological implications of controlled atmosphere storage of 'Conference' pears (Pyrus communis L.): a proteomic approach. Postharvest Biol. Technol. 50, 110-116.

Pedreschi, R., Vanstreels, E., Carpentier, S., Hertog, M., Lammertyn, J. Robben, J., et al. (2007). Proteomic analysis of core breakdown disorder in Conference pears (Pyrus communis L.). Proteomics 7, 2083-2099.

Perotti, V. E., Vecchio, H. A. D. Sansevich, A., Meier, G., Bello, F., Cocco, M., et al. (2011). Proteomic, metabalomic, and biochemical analysis of heat treated Valencia oranges during storage. Postharvest Biol. Technol. 62, 97-114.

Posner, M., Kiss, A. J., Skiba, J. Drossman, A., Dolinska, M. B., Hejtmancik, J. F., et al. (2012). Functional validation of hydrophobic adaptation to physiological temperature in the small heat shock protein $\alpha$ A-crystallin. PLoS ONE 7:e34438. doi: 10.1371/journal.pone.0034438

Prinsi, B., Negri, A. S., Fedeli, C., Morgutti, S., Negrini, N., Cocucci, M., et al. (2011). Peach fruit ripening: a proteomic comparative analysis of the mesocarp of two cultivars with different flesh firmness at two ripening stages. Phytochemistry 72 1251-1262.

Qin, G. Z., Liu, J., Cao, B. H., Li B. Q., and Tian, S. P. (2011) Hydrogen peroxide acts on sensitive mitochondrial proteins to induce death of a fungal pathogen revealed by proteomic analysis. PLoS ONE 6:e21945. doi 10.1371/journal.pone.0021945

Qin, G. Z., Tian, S. P., Chan, Z. L., and Li, B. Q. (2007). Crucial role of antioxidant proteins and hydrolytic enzymes in pathogenicity of Penicillium expansum: analysis based on proteomic approach. Mol. Cell. Proteomics 6, 425-438.

Qin, G. Z., Tian, S. P., Liu, H. B., and $\mathrm{Xu}$, Y. (2002). Polyphenol oxidase, peroxidase, and phenylalanine ammonium lyase induce in postharvest peach fruit by inoculation with Pichia membranefaciens or Rhizopus stolonifer. Agric. Sci. China 1, 1242-1249.

Quirino, B. F., Candido, E. S., Campos, P. F., Franco, O. L., and Krüger, R. H. (2010). Proteomic approaches to study plant-pathogen interactions. Phytochemistry 71, 351-362.

Robertson, F. P., Koistinen, P. K., Gerrish, C., Halket, J. M., Patel, R. K., Fraser, P. D., et al. (2012). Proteome changes in tomato lines transformed with phytoene synthase- 1 in the sense and antisense orientations. J. Exp. Bot. 63 , 6035-6043

Rocco, M., D'Ambrosio, C., Arena, S., Faurobert, M., Scaloni, A., and Marra, M. (2006). Proteomic analysis of tomato fruits from two ecotypes during ripening. Proteomics 6 , 3781-3791.

Ryals, J. A., Neuenschwander, U. H., Willits, M. G., Molina, A., Steiner, H. Y., and Hunt, M. D. (1996). Systemic acquired resistance. Plant Cell 8, 1809-1819.

Salunkhe, D. K., Bolin, H. R., Reddy, N. R., Salunkhe, D. K., Bolin, H. R., and Reddy, N. R. (1991). Storage, Processing, and Nutritional Quality of Fruits and Vegetables, Vol. 2. Boca Raton, FL: CRC Press, 217-236.

Sánchez-Bel, P., Egea, I., SánchezBallesta, M. T., Martinez-Madrid, C., Fernandez-Garcia, N., Romojaro, F., et al. (2012). Understanding the mechanisms of chilling injury in bell pepper fruits using the proteomic approach. J. Proteomics 75, 5463-5478.

Sarry, J.-E., Sommerer, N., Sauvage, F.-X., Bergoin, A., Rossignol, M., Albagnac, G., et al. (2004). Grape berry biochemistry revisited upon proteomic analysis of the mesocarp. Proteomics 4, 201-215.

Schirra, M., D'Aquino, S., Cabras, P., and Angioni, A. (2011). Control of postharvest diseases of fruit by heat and fungicides: efficacy, residue levels, and residue persistence. A review. J. Agric. Food Chem. 59, 8531-8542.

Schirra, M., D'Aquino, S., Palma, A., Angioni, A., and Cabras, P. (2008a). Factors affecting the synergy of thiabendazole, sodium bicarbonate, and heat to control postharvest green mold of citrus 
fruit. J. Agric. Food Chem. 56, 10793-10798.

Schirra, M., D'Aquino, S., Mulas, M., Melis, R. A., Giobbe, S., Migheli, Q., et al. (2008b). Efficacy of heat treatments with water and fludioxonil for postharvest control of blue and gray molds on inoculated pears and fludioxonil residues in fruit. J. Food Prot. 71, 967-972.

Shah, P., Gutierrez-Sanchez, G., Orlando, R., and Bergmann, C. (2009). A proteomic study of pectin-degrading enzymes secreted by Botrytis cinerea grown in liquid culture. Proteomics 9, 3126-3135.

Shah, P., Powell, A. L., Orlando, R., Bergmann, C., and GutierrezSanchez, G. (2012). Proteomic analysis of ripening tomato fruit infected by Botrytis cinerea. J. Proteome Res. 11, 2178-2192.

Shi, J. X., Chen, S., Gollop, N., Goren, R., Goldschmidt, E. E., and Porat, R (2008). Effects of anaerobic stress on the proteome of citrus fruits. Plant Sci. 175, 478-486.

Sivakumar, D., Arrebola, E., and Korsten, L. (2008). Postharvest decay control and quality retention in litchi (cv. McLean's Red) by combined application of modified atmosphere packaging and antimicrobial agents. Crop Prot. 27, 1208-1214.

Sommer, N. F. (1982). Postharvest handling practices and postharvest diseases of fruits. Plant Dis. 66, 357-363.

Sticher, L., Mauch-Mani, B., and Metraux, J. P. (1997). Systemic acquired resistance. Аnnu. Rev. Phytopathol. 35, 235-270.

Terry, L. A., and Joyce, D. C. (2004). Elicitors of induced disease resistance in postharvest fruits: a brief review. Postharvest Biol. Technol. 32, $1-13$.

Tian, S. P., and Chan, Z. L. (2004). Potential of induced resistance in postharvest diseases control of fruits and vegetables. Acta Phytopathol. sinica 234, 385-394.

Tian, S. P., and Fan, Q. (2000). Biological technologies for the control of postharvest diseases of fruits and vegetables. Chin. Bull. Bot. 17, 211-217.

Tian, S. P., Fan, Q., Xu, Y., and Wang, Y. (2001). Effects of Trichosporon sp. in combination with calcium and fungicide on biocontrol of postharvest diseases in apple fruits. Acta Bot. Sin. 43, 501-505.

Tian, S. P., Li, B. Q., and Xu, Y. (2005a). Effects of $\mathrm{O}_{2}$ and $\mathrm{CO}_{2}$ concentrations on physiology and quality of litchi fruit in storage. Food Chem. 91, 659-663.

Tian, S. P., Qin, G. Z., and Xu, Y. (2005b). Synergistic effects of combining biocontrol agents with silicon against postharvest diseases of jujube fruit. J. Food Protect. 68, 544-550.

van Kan, J. A. (2006). Licensed to kill: the lifestyle of a necrotrophic plant pathogen. Trends Plant Sci. 11, 247-253.

van Loon, L. C. (1997). Induced resistance in plants and the role of pathogenesis- related proteins. Eur. J. Plant Pathol. 103, 753-765.

Villa-Rojas, R., López-Malo, A., and Sosa-Morales, M. E. (2011). Hot water bath treatments assisted by microwave energy to delay postharvest ripening and decay in strawberries (Fragaria $\times$ ananassa). J. Sci. Food Agric. 91, 2265-2270.

Wang, K., Peng, J., Tang, S. S., Shang, H. T., Rui, H. J., Di, H. T., et al. (2011). Improved control of postharvest decay in Chinese bayberries by a combination treatment of ethanol vapor with hot air. Food Control 22, 82-87.

Wang, Q., Chan, Z. L., Qin, G. Z., and Tian, S. P. (2009a). Comparison of 2-DE techniques for improved proteomic analysis of fruit tissues. Chin. Bull. Bot. 44, 107-116.

Wang, Q., Qin, G. Z., Lai, T. F., and Tian, S. P. (2009b). Response of jujube fruit to exogenous oxalic acid treatment based on proteomic analysis. Plant Cell Physiol. 50, 230-242.

Williamson, B., Duncan, G. H., Harrison, J. G., Harding, L. A., Elad, Y., and Zimand, G. (1995). Effect of humidity on infection of rose petals by dry-inoculated conidia of Botrytis cinerea. Mycol. Res. 99, 1303-1310.

Williamson, B., Tudzynski, B. Tudzynski, P., and van Kan, J. L. (2007). Botrytis cinerea: the cause of grey mould disease. Mol. Plant Pathol. 8, 561-580.

Wu, F., Zhang, D., Zhang, H., Jiang, G., Su, X., Qu, H., et al. (2011). Physiological and biochemical response of harvested plum fruit to oxalic acid during ripening or shelf-life. Food Res. Int. 44, 1299-1305.

Yao, H. J., and Tian, S. P. (2005) Effect of pre- and post-harvest application of salicylic acid or methyl jasmonate on inducing disease resistance of sweet cherry fruit in storage. Postharvest Biol. Technol. 35, 253-262.

Yun, Z., Jin, S., Ding, Y., Wang, Z., Gao, H., Pan, Z., et al. (2012). Comparative transcriptomics and proteomics analysis of citrus fruit to improve understanding of the effect of low temperature on maintaining fruit quality during lengthy post-harvest storage. J. Exp. Bot. 63 , 2873-2893.

Yun, Z., Li, W., Pan, Z., Xu, J., Cheng, Y., and Deng, X. (2010). Comparative proteomics analysis of differentially accumulated proteins in juice sacs of ponkan (Citrus reticulata) fruit during postharvest cold storage. Postharvest Biol. Technol. 56, 189-201.

Zhang, C., Ding, Z., Xu, X., Wang, Q., Qin, G., and Tian, D. (2010). Crucial roles of membrane stability and its related proteins in the tolerance of peach fruit to chilling injury. Amino Acids 39, 181-194.

Zhang, H., Wang, L., Zheng, X., and Dong, Y. (2007). Effect of yeast antagonist in combination with heat treatment on postharvest blue mold decay and Rhizopus decay of peaches. Int. J. Food Microbiol. 115, 53-58.

Zhang, L., Yu, Z., Jiang, L., Jiang, J., Luo, H., and Fu, L. (2011). Effect of post-harvest heat treatment on proteome change of peach fruit during ripening. J. Proteomics 74, 1135-1149.

Zhao, Y., Tu, K., Su, J., Tu, S., Hou, Y., Liu, F., et al. (2009). Heat treatment in combination with antagonistic yeast reduces diseases and elicits the active defense responses in harvested cherry tomato fruit. J. Agric. Food Chem. 57, 7565-7570

Zheng, X. L., and Tian, S. P. (2006). Effect of oxalic acid on control of postharvest browning of litchi fruit. Food Chem. 96, 519-523.

Zheng, X. L., Tian, S. P., Gidley, M. J., Yue, H., and Li, B. Q. (2007a). Effects of exogenous oxalic acid on ripening and decay incidence in mango fruit during storage at room temperature. Postharvest Biol. Technol. 45, 281-284.

Zheng, X. L., Tian, S. P., Meng, X. H., and Li, B. Q. (2007b). Physiological and biochemical responses in peach fruit to oxalic acid treatment during storage at room temperature. Food Chem. 104, 156-162.

Conflict of Interest Statement: The author declares that the research was conducted in the absence of any commercial or financial relationships that could be construed as a potential conflict of interest.

Received: 04 October 2012; paper pending published: 07 November 2012; accepted: 24 December 2012; published online: 10 January 2013.

Citation: Chan Z (2013) Proteomic responses of fruits to environmental stresses. Front. Plant Sci. 3:311. doi: 10.3389/fpls.2012.00311

This article was submitted to Frontiers in Plant Proteomics, a specialty of Frontiers in Plant Science.

Copyright (9) 2013 Chan. This is an open-access article distributed under the terms of the Creative Commons Attribution License, which permits use distribution and reproduction in other forums, provided the original authors and source are credited and subject to any copyright notices concerning any thirdparty graphics etc. 